SPE paper 17542

\title{
Permeability Damaze to Natural Fractures Caused by Fracturing Fluid Polymers
}

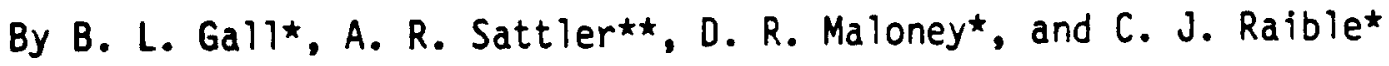 \\ SAND--87-2514C \\ DE88 007584
}

\section{COPYRIGHT WAIVER}

By acceptance of this article for publication, the publisher recognizes the Governaent's (license) rights in any copyright and the government and its authorized representatives have unrestricted rights to reproduce in whoie or in part said article under any copyright secured by the publisher.

\section{DISCLAIMER}

\begin{abstract}
This report was prepared as an account of work sponsored by an agency of the United States Government. Neither the United States Government nor any agency thereof, nor any of their employees, makes any warranty, express or implied, or assumes any legai liability or responsibility for the accuracy, completeness, or usefulness of any information. apparatus, product, or process disclosed, or represents that its use would not infringe privately owned rights. Reference herein to any specific commercial product, process, or service by trade name, trademark, manuf acturer, or otherwise, does not necessarily constitute or imply its endorsement, recommendation, or favoring by the United States Government or any agency thereof. The views and opinions of authors expressed herein do not necessarily state or reflect those of the United States Government or any agency thereof.
\end{abstract}

\section{DISCLAIMER}

\footnotetext{
Gall. Sattler, and Raible are SPE members.

* National Institute for Petroleum and Energy Research * Sandia National Laboratories
}

This report was prepared as an account of work sponsored by an agency of the United States Government. Neither the United States Government nor any agency thereof, nor any of their mes any warranty, express or implied, or assumes any legal liability or responsiility bility for the accuracy, complents that its use would not infringe privately owned rights. Referprocess disclosed, or represents that its use woct, process, or service by trade name, trademark, ence herein to any specific commercial prodsarily constitute or imply its endorsement, recommanufacturer, or otherwise does not necessarily constitut or any agency thereof. The views mendation, or favoring by the United States Governmessarily state or reflect those of the and opinions of authors expressed herein do not
United States Government or any agency thereof. 


\section{DISCLAIMER}

This report was prepared as an account of work sponsored by an agency of the United States Government. Neither the United States Government nor any agency Thereof, nor any of their employees, makes any warranty, express or implied, or assumes any legal liability or responsibility for the accuracy, completeness, or usefulness of any information, apparatus, product, or process disclosed, or represents that its use would not infringe privately owned rights. Reference herein to any specific commercial product, process, or service by trade name, trademark, manufacturer, or otherwise does not necessarily constitute or imply its endorsement, recommendation, or favoring by the United States Government or any agency thereof. The views and opinions of authors expressed herein do not necessarily state or reflect those of the United States Government or any agency thereof. 


\section{DISCLAIMER}

Portions of this document may be illegible in electronic image products. Images are produced from the best available original document. 


\section{Penmeability Damage to Natural Fractures Caused by}

Fracturing Fluid Polymers

By B. L. Gall, A. R. Sattler, D. R. Maloney, and C. J. Raible

ABSTRACT

Formation damage studies using artifically fractured, low-permeability sandstone cores indicate that viscosified fracturing fluids can severely restrict gas flow through these types of narrow fractures. These studies were performed in support of the Department of Energy's Multiwell Experiment $(M W X)$. The MWX program was a coordinated research effort to study methods to evaluate and enhance gas production from low-permeability lenticular reservoirs of the Western United States.

Extensive geological and production evaluations at the MWX site indicate that the presence of a natural fracture system is largely responsible for unstimulated gas production. The laboratory formation damage studies were designed to examine changes in cracked core permeability to gas caused by fracturing fluid residues introduced into such narrow fractures during fluid leakoff.

Polysaccharide polymers caused significant reduction (up to 95\%) to gas flow through cracked cores. Polymer fracturing fluid gels used in this study included hydroxypropyl guar, hydroxyethyl cellulose, and xanthan gum. In contrast, polyacrylamide gels caused little or no reduction in gas flow through cracked cores after liquid cleanup. Other components of fracturing fluids (surfactants, breakers, etc.) caused less damage to gas flows.

The resuits of fluid leakoff tests indicated that polysaccharide polymers caused a filter cake buildup at or near the crack entrance while polyacrylamide polymers did not cause a filtercake buildup within the time period of the tests. For xanthan gum gels filtercake buildup was reduced for gels containing polymer breakers. For gels containing polymer breakers, 100 mesh sand was an effective fluid-loss control agent for narrow fractures.

Other factors affecting gas flow through cracked cores were investigated, including the effects of net confining stress and non-Darcy flow parameters.

Results are related to some of the problems observed during the 
stimulation program conducted for the MWX.

\section{INTRODUCTION}

The MWX has been an extensive program to characterize and stimulate gas production from low-permeability lenticular gas reservoirs of the Western United States. Three closely spaced wells were drilled into the Cretaceous Mesaverde group in Garfield County near Rifle, Colorado. After extensive geological and geophysical characterization, a series of stimulation treatments were performed in sandstones of the paludal, coastal, and fiuvial intervals of the Williams Fork formation at the MWX site. A number of reports have been published which describe the work that has been performed at the MWX site. ${ }^{1-6}$ Core studies ${ }^{7-9}$ indicated that dry core matrix permeabilities to gas at reservoir stress conditions were less than $10 \mu d$ and frequently less than $3 \mu \mathrm{d}$. At typical levels of water saturation for the reservoir, these values may be reduced by an order of magnitude. Porosities ranged from 3 to 12\%. Clays generally averaged less than $10 \%$ and were predominantly illite and mixed-layer clays. Reservoir permeabilities derived from production data were higher than permeabilities measured for core plugs, indicating the presence of a natural fracture system in the reservoir. Extensive core and outcrop studies also showed the presence of a natural fracture system composed of narrow mineralized fractures which, in some regions, appeared to be subparallel.

Initial stimulation treatments used non-crosslinked or crosslinked hydroxypropyl guar (HPG) to viscosify the fracturing fluids. However, later fracture treatments were conducted using foamed fracturing fluids to reduce the amount of water and organics injected into the formation. The foams contained a biopolymer, xanthan gum, to gel the base fracturing fluid.

Extensive laboratory studies have been conducted on the fracturing materials used for all stages of the MWX stimulation program. ${ }^{10-12}$ These studies included formation damage, fluid-loss, proppant embedment and conductivity, and polymer degradation.

This paper describes the results of tests on permeability damage to fractured MWX cores caused by fracturing fluid components. Fluid-loss through cracked cores for different fluid systems will be described. In addition, non-Darcy gas flow parameters have been estimated for gas flow through narrow 
fractures.

PROCEDURES

MWX core plugs were cracked and reassembled under reservoir net stress and temperature conditions. The artificially produced cracks resembled many natural fractures observed in MWX cores in shape and size but lacked calcite cementation associated with the naturally occurring fractures.

The apparatus used to simulate formation damage has been described previously. $^{13-14}$ The apparatus allowed pressurized liquids to flow across the face of the core. The fluid that leaked off through the core or crack could be measured. Gas flow was measured in the opposite direction to liquid flow. Table 1 lists the typical experimental conditions for the formation damage tests and gas permeability measurements.

Permeabilities to gas of cracked MWX cores declined after exposure to any type of aqueous-based liquids. Since the objective of this study was to determine the effects of fracturing fluid components on gas permeability, the cracked cores were initially conditioned by saturating with brine ( 2 to $3 \% \mathrm{KCl}$ ) at reservoir stress conditions. Gas permeabilities after brine saturation and gas cleanup were determined, and the results were compared to gas permeabilities measured after fracturing fluid injection and gas cleanup. The change in gas permeability was used to estimate flow impairment caused by fracturing fluid residues.

A variety of fracturing fluid formulations of interest to the MWX stimulation program were tested. Sandstones of the paludal zone were stimulated with gelled HPG fracturing fluid. Sandstones of the coastal and fluvial intervals were fractured using foam stabilized with xanthan gum. Two other polymer types were tested for comparative purposes, hydroxyethy 1 cellulose (HEC) and polyacrylamide. HPG, xanthan gum, and HEC are polysaccharides. Polyacrylamide, however, is a synthetic polymer with a different molecular structure.

In addition, the fracturing fluids contained various salts or buffers, foam surfactants, gel breakers, and fluid loss agents. A few tests were conducted to determine the damaging effects of these components alone on cracked core permeability to gas. Table 2 lists the composition of the various fluids tested during the study. Fluid components will not be 
identified further for proprietary considerations.

\section{RESULTS}

\section{Gas Permeability Reductions/Non-Polymer Solutions}

In these laboratory tests, reductions in gas permeabilities were observed after injection and cleanup for all liquids tested. Conditioning procedures were performed to minimize the effects of brine saturation on fracturing fluid permeability damage tests. Separate tests were also conducted to determine the degree of permeability damage caused by non-polymer fracturing fluid additives such as surfactants and polymer breaker.

Table 3 shows the results of representative tests for solutions containing non-polymer additives. The foam fracturing fluid surfactants reduced gas permeability by $25 \%$. The surfactant/breaker solutions caused reductions up to 50\%. However, non-polymer fracturing fluid components caused less gas flow impairment than some types of polymer gels, as described in the next section.

\section{Gas Permeability Reductions/Polymer Gels}

The results of several permeability damage tests using cracked MWX cores and different polymer gels are listed in Table 4. Results were affected by two very different parameters: initial gas permeability and polymer types.

For cores containing higher permeability cracks (greater than $0.5 \mathrm{md}$ ), polymer gels reduced gas flow by approximately 50\%. This level of permeability damage should not be a limiting factor for gas production through cracks of this type (if they exist in the reservoir); $;^{16}$ however, one problem with wide cracks could be the control of fluid leakoff during a fracture stimulation.

In most of the laboratory tests, however, reassembled cracked cores had initial gas permeabilities less than $0.5 \mathrm{md}$. For cores containing narrow cracks, polymer type was the main factor affecting gas flow impairment. In general, the permeability reduction for gas flow through cracked cores was very high for all of the polysaccharide polymers. In contrast, for three laboratory tests, polyacrylamide gels resulted in only a small decrease in gas flow through the cracked cores. The decrease in gas flow caused by 
polyacrylamide ge 1 residues was less than $5 \%$ of the initial undamaged permeability.

The addition of fine-mesh sand had little noticeable effect on cracked core damage results; however, the fine-mesh sand did reduce the rate of fluid leakoff through the crack.

The addition of breakers to degrade the polymer gels also did not significantly reduce gel residue damage to gas flow through the cracks. However, experimental conditions of the laboratory tests may have contributed to this result. The ineffectiveness of polymer breaker to reduce polymer damage to gas flow in MWX cores has been studied previously. '1 The breaker solution can leak off through a polymer filtercake buildup leaving insufficient breaker to react with the concentrated polymer.

Several tests were conducted to determine if a more concentrated breaker solution would increase cracked core gas permeability. For a cracked core damaged with HPG residues, effective permeability to gas increased from 0.020 to 0.042 md after treatment with a higher concentration of oxidant breaker solution ( $1 \%$ ammonium persulfate). However, xanthan gum residues were not affected by a solution containing 10 times the normal concentration of oxidant breaker ( $\mathrm{LiOCl}$ ). A more efficient breaker system was designed for the xanthan gelled foam fracturing fluid and used in the fourth MWX stimulation. This breaker system is proprietary and will not be described in this paper.

In summary, polymer residues from polysaccharide polymers such as HPG and xanthan gum caused significant permeability reductions for low-permeability cores containing fractures. A different polymer type (polyacrylamide) was nondamaging. The use of gel breakers and fine mesh sand did not affect laboratory permeability damage tests, but they may be more effective in field applications.

\section{Fluid Leakoff Through Cracked Cores}

During permeability damage tests, fluid leakoff through the cracked MWX cores was measured as a function of the square root of time. During any specific test, fluid leakoff could be affected by crack size, fluid composition, or location of polymer buildup on the core surface or within a crack. Similar variations have been observed in fluid-loss tests using 
liquids containing suspended solids and filtration media of different pore sizes. ${ }^{17}$

Fig. 1 shows fluid accumulation as a function of the square root of time for several different fluid types. Table 5 lists liquids used for the tests and gas permeabilities measured before and after the tests.

In all tests, viscous polymer solutions passed through the cracks; however, 100-mesh sand was usually filtered from the gel at or near the entrance to the crack. Fig. 1 illustrates the effects of solution components on fluid-loss through the lower permeability cracked cores.

The fluids used for tests 1 through 3 contained nondegraded polysaccharide polymers. These fluids effectively formed filtercakes that controlled fluidloss through the cracked cores of permeability less than $0.2 \mathrm{md}$. For these polymer solutions, spurt loss was zero or less than zero. Curve 4 shows fluid-loss for a solution of xanthan gum with breaker. The spurt loss is much higher, indicating a less efficient filtercake bulidup. Higher spurt loss was observed for all tests with fluids containing xanthan gum and breaker unless 100 mesh sand was added to the gel. In tests not illustrated in Fig. 1, 100 mesh sand helped to reduce total fluid leakoff through the cracks to correspond with the totals shown for tests 2 and 3 in Fig. 1. The 100 mesh sand was a good fluid-loss agent for this type of crack. For all these tests, however, damage to gas permeability was significant.

Curve 5 in Fig. 1 represents fluid leakoff of polyacrylamide through a cracked core. The actual rate of liquid flow through the crack was linear with time for an entire 2-hour test. No filtercake buildup occurred. This test also produced little damage to gas permeability. Plugging of the main flow channels or buildup of polymer residues was minimal with respect to possible gas flow restrictions.

Additional studies included measurement of fluid-loss through "high" permeability cracks. For these cracks, fluid-loss was usually a linear function of time for a 2-hour test. Sand was not filtered out of the gel because particle size in the liquid was too small to allow particle bridging and filtercake buildup within the crack. Correspondingly, gas permeability damage was less severe for these wide-open cracks and should not cause problems in gas production after a reservoir stimulation. In the reservoir, 
formations with wide natural fractures would result in a high rate of fluid leakoff during a hydraulic fracture stimulation. Fluid-loss agents such as 100-mesh (or smaller) sand were ineffective in controlling liquid flow into fairly open cracks.

\section{Crack Permeability vs. Net Stress}

Several studies reported in the literature have examined the effects of confining stress and pore pressure on the permeability of fractured core. ${ }^{18-20}$ For fluid flow mainly through the fracture rather than the rock matrix, both empirical and theoretical studies have predicted that permeability is related to effective stress $\left(P_{e}\right)$ as

$$
k^{1 / 3}=A-B \log P_{e}
$$

where $A$ and $B$ are constants.

For example, Jones ${ }^{19}$ found that his fit to Eq. 1 was independent of the types of the cracks in his cores. These included both artifically and naturally fractured cores as well as fracture systems with and without secondary mineralization.

Several experiments were conducted to examine the effects of net stress on cracked core permeability before and after treatment with several types of aqueous solutions. The results from one series of tests are shown in fig. 2. Permeability to gas declined as net stress increased for each fluid treatment.

Permeability as a function of net stress was reasonably reproducible for two brine saturation tests. Treatment with surfactant solutions and gelled polymer caused further declines in gas permeability. Pore pressure decline magnified gas permeability reductions.

These results demonstrated the sensitivity of crack permeability to net stress measurement conditions. If reservoir production reduces pore pressure significantly, additional reductions in reservoir permeability may result as the fracture system closes. 


\section{Non-Darcy Flow Parameters for Cracked Cores}

The matrix permeabilities of cores used in this study were less than 0.003 md; therefore, most if not all of the measured gas flow was through the crack. An estimate of crack dimensions, however, would be required to estimate gas flow parameters for the cracks alone. Several experiments were performed to estimate crack dimensions and measure non-Darcy flow parameters for gas flow through narrow cracks. Results of these experiments were compared to non-Darcy flow parameters reported for sandpacks and consolidated cores.

The crack dimensions were estimated by filling the cracks with Wood's metal. The same conditions of confining stress were maintained on the cores as were used during gas flow measurements. Thin sections were then prepared, and crack dimensions were measured by microscopic examination of the Wood's metal filled crack.

The average crack width was $60 \mu \mathrm{m}$ for a dry (unconditioned) crack and 15 to $30 \mu \mathrm{m}$ for cracks exposed to brine or gel. Some of the narrow dimensions were $5 \mu \mathrm{m}$ or less for cracks damaged by gel contact. In addition, Wood's metal failed to completely fill part of the gel-damaged cracks which were partially blocked by polymer residues.

The non-Darcy flow parameters were calculated using an integrated form of Forchheimer's equation:

$$
\frac{(1+b / P)\left(P_{1}{ }^{2}-P_{2}{ }^{2}\right)(M)}{2 L Z R T_{\mu}(W / A)}=\frac{1}{k_{\infty}}+B \frac{W}{H A}(1+b / P)
$$

Fig. 3 shows the analysis for gas flow through gel-damaged, cracked core MWX-1 5478.9 B by use of Eq. 2. Several different values of $b$, the gas slippage factor, were used to determine a "best fit" for the data. The slope of the plot is $B$ and the intercept is the inverse of the absolute gas permeability, $k_{\infty}$. For this example, $b=0.2$ atm provided the best fit. For other tests, values of $b$ ranged from 0 , for a high-permeability dry crack, to 0.4 for another gel-damaged crack of lower permeability. In all cases, b values were much lower than for the MWX core matrix (approximately $3.5 \mathrm{~atm}$ ). Instead, the $b$ values compare with $b$ values measured for consolidated cores of corresponding permeability. 
Table 6 shows $k$ and $\beta$ results for four low-permeability cracked cores that were exposed to different liquid treatments. Because of the uncertainty in the crack area, data analysis was performed using two different estimates of crack area to cover the average range of crack width ${ }^{5}$ estimated by the thin section measurements. By increasing the crack area by a factor of two, $k$ decreased by a factor of two, and $\beta$ increased by a factor of four.

Fig. 4 shows a plot of $\beta$ versus $k$ for the data presented in Table 6 . Also shown on the figure are plots of $\beta$ versus $k$ for proppant pack; of several different proppant size distributions. ${ }^{21}$ The cracked core data fall along a line with similar slope to the proppant pack data but of fset toward lower permeability by an order of magnitude. The dashed line represents the correlation of $B$ and $k$ values for 355 sandstone and 29 limestone cores, as reported by S. C. Jones. ${ }^{22}$ Both unconsolidated and consolidated $B$ and $k$ values can be correlated if sample porosity can be considered. ${ }^{21}$

The cracked core results fall within the lower boundary of consolidated core data used for Jones' correlation. Note that the $\beta^{\prime} s$ for cracks are comparable to data obtained from consolidated cores; that is, cores and cracks with the same permeability have similar $B$ 's. However, further studies would be desirable to more clearly define this relationship. Noman and Archer ${ }^{23}$ showed that consolidated cores with the same measured gas permeability could have different values for 8 . By examining the pore structure of the rocks, they were able to attribute differences to pore connectivity and pore to pore throat size for the different samples. A crack could be considered to have well connected flow channels which could reduce inertia flow effects when compared to consolidated material of the same permeability. This would result in values of $B$ and $k$ on the low side of the consolidated core data, as was found in this study.

Further studies using more sophisticated techniques to estimate crack areas would be required before crack permeabilities could be reported with assurance. Liquid contact and gel damage, however, cause reductions in crack permeability and corresponding increases in the non-Darcy 8 factor when compared to nondamaged or dry cracks.

\section{Relationship to Field Results}

Four stimulations have been carried out at the MWX site since 1984. The 
sustained gas production before and after the stimulation treatments is summarized in Table 7. For the first three stimulations, the question of damage to the natural fracture system could not be eliminated. In fact, the laboratory work that extensive damage to crack permeability is possible.

The paludal zone stimulation has been described extensively in the 1iterature. ${ }^{5}, 6$ The disappointing gas production after the stimulation was attributed to fracturing fluid damage to the natural fracture system. After an extended well shut-in of 18 months, gas production increased. The exact reasons or factors responsible for higher gas production rates are not known; however, several factors involving transitory damage to the natural fracture system have been proposed. Capillary forces could cause a redistribution of liquids within the reservoir and result in the removal of water from the natural fractures. In addition, polymer residues in the fracture could decompose at reservoir temperatures of $200^{\circ} \mathrm{F}(363 \mathrm{~K})$.

Subsequent stimulations used a foam fracturing fluid to minimize the quantity of fluid (water and organics) injected into the reservoir. The base fluid for the foam was a xanthan gum gel. Stimulation with foam for the coastal and fluvial ' $B$ ' sandstones resulted in a screen out followed by a very limited increase in gas production. Analyses of these stimulations are continuing; however, based on the laboratory results reported here, it is possible that gel damage to an existing natural fracture system contributed to the limited increase in gas production after the stimulations.

Finally, for a subsequent stimulation in the fluvial ' $E$ ' zone, every effort was made to design and use a fluid system which would leave only minimal amounts of polymer in the natural fractures. A prepad containing a high concentration of polymer breaker was placed ahead of the fracturing fluid. Upon well flowback, contact with breaker could help mobilize the polymer gel in the natural fractures. Fluid leakoff was controlled by using 100 mesh sand. Initial field results were encouraging. The breaker design and application will be described in greater detail in an upcoming SPE paper. ${ }^{24}$

\section{DISCUSSION}

Damage to the narrow natural fracture system at the MWX site appeared to be an important factor in determining post-fracture gas production. The simulation of well productivity after a hydraulic fracture treatment indicated 
that formation permeability damage must be high to cause significant problems with gas production. ${ }^{16}$ Fracturing fluid gels did not cause this degree of permanent damage to MWX matrix permeability to gas. ${ }^{25}$ However, in this study, large permeability reductions were observed for gas flow through narrow fractures. Gelled fracturing fluids could enter these channels and leave behind residues which could not be removed by gas flow. Polysaccharide polymers such as HPG, HEC, and xanthan gum caused similar levels of permeability reduction. A different polymer type (polyacrylamide), however, was essentially nondamaging after a typical 2-hour leakoff test. Polymer breakers and fluid-loss agents in the gel were not helpful in reducing permeability damage.

One test, however, suggested that pretreatment of the fractures may reduce polymer damage. A pad of polyacrylamide ahead of the polysaccharide resulted in final gas permeability of $0.042 \mathrm{md}$ (matrix plus crack) rather than the typical 0.017 to $0.025 \mathrm{md}$ range. This result suggests that some treatments could be included in the prepad or pad to discourage polymer residue accumulation in the reservoir. At the MWX, a different approach resulted in the use of a designed polymer breaker system both ahead of and incorporated with the fracturing fluid. This stimulation resulted in a significant increase in gas production.

\section{SUMMARY}

A laboratory study was conducted to determine what effects hydraulic fracturing fluid treatments would have on naturally fractured reservoirs such as those located at the MWX site. Experiments were designed to test the effects of fractures at simulated reservoir conditions. Most of the tests were performed using artificially fractured cores because naturally fractured cores were unavailable for tests of this type.

Permeability damage tests were conducted using four types of polymer gels. Gel residues of polysaccharide polymers (HPG, HEC, and xanthan gum) caused severe reduction in gas flow up to $95 \%$ through narrow cracks. Permeability reduction was attributed to gel residues deposited in the cracks. However, for several tests, polyacrylamide gels were relatively nondamaging to gas flow through cracked cores. Polyacrylamide gel residues caused less than a $5 \%$ reduction in permeability to gas. 
Results of fluid-loss tests also indicated a difference between polysaccharide and polyacrylamide gel filter cake buildup or polymer accumulation in the fractures. The filter cake buildup in the fractures associated with polysaccharide gels resulted in plugging of the fracture by gel residues. In contrast, filter cake buildup was not evident with the polyacrylamide, and little gel residue remained in the fractures to block or restrict gas flow after gel cleanup. Increased leakoff rates with polymer solutions containing breakers suggested that buildup of polymer residues in the crack was slower than with non-breaker gels.

In this study, gas permeabilities of cracked cores were also shown to be a function of net confining stress. Crack dimensions can be changed by changing the net stress on the cores. Crack dimensions were estimated in order to estimate crack permeability. Non-Darcy flow parameters were also estimated for damaged and nondamaged cracked cores. Results were compared to non-Darcy flow parameters for consolidated cores and unconsolidated sandpacks.

\section{CONCLUSIONS}

Based on the results of this laboratory study, we have made the following conclusions:

- Fracturing with polysaccharide gelled fracturing fluids may damage narrow fractures in a naturally fractured reservoir. Gel polymer residues deposited in natural fractures intersected by hydraulic fractures will result in restricted gas flow. Although a fracture treatment may result in some increased gas production, the overall increase in gas production will be less than expected from the stimulation treatment because of polymer residue damage to the natural fracture system.

- Pretreatment of natural fractures may be one method to reduce polymer damage. One test indicated that polyacrylamide placed ahead of a polysaccharide reduced damage to gas permeability.. High breaker concentrations reduced permeability damage caused by HPG gels. For the MWX fluvial 'E' zone stimulation, higher than normal breaker concentration in the pad was used to help reduce xanthan gum polymer residues in the natural fractures.

- Polyacrylamide gels cause little damage to narrow fractures in this study. Further studies should be conducted to determine whether other 
properties of polyacrylamide gels (shear-sensitive, leakoff properties, saltsensitive, cost) prohibit their use as fracturing fluids.

- The addition of breaking agents at low concentrations recommended for stimulation treatments may be of some help in reducing polymer residues and damage to gas flow in narrow fractures. Higher or more efficient breaker concentrations, however, may be required to minimize permeability damage caused by polysaccharide polymer residues.

- Crack permeability is sensitive to changes in stress. Pressure drawdown in a naturally fractured reservoir could cause reductions in gas permeability. 


\section{ACKNOWLEDGEMENTS}

The authors wish to thank Karl Rosentrater of NIPER for his excellent assistance in the laboratory. Thanks are also expressed to the Department of Energy for financial support; in particular, Karl Frohne, Manager of the Western Gas Sands Project, and Jim White of DOE Headquarters.

\section{Conversion Factors}
1 darcy
$=9.869 \times 10^{-9} \mathrm{~cm}^{2}$
$1 \mathrm{~atm}-\mathrm{sec}^{2} / \mathrm{gram}=1.01325 \times 10^{6} \mathrm{~cm}^{-1}$
$1 \mathrm{~atm}$
$=1.01325 \times 10^{-1} \mathrm{MPa}$

\section{NOMENCLATURE}

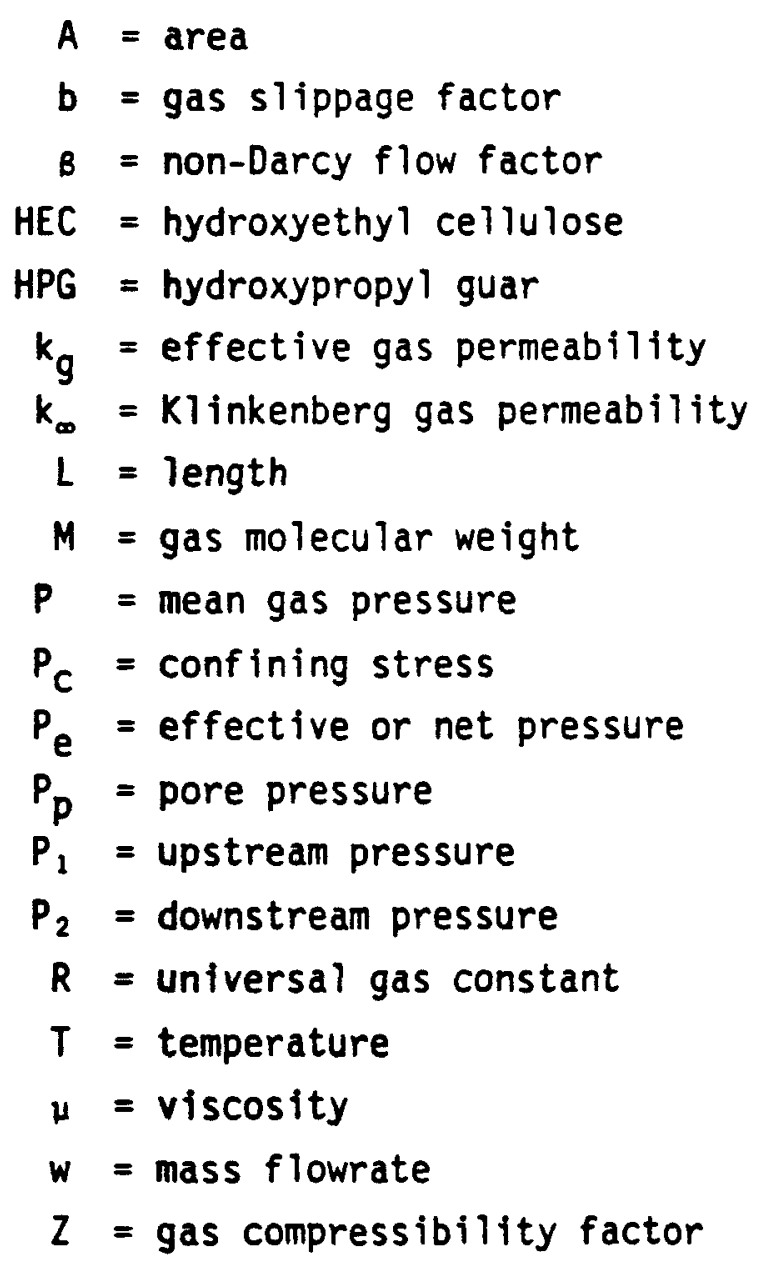




\section{REFERENCES}

1. Northrup, D. A., A. R. Sattler, R. L. Mann, and K. H. Frohne. Current Stat is of the Multiwell Experiment. Pres. at SPE/DOE/GRI Unconventional Gas Recovery Symp., Pittsburgh, PA, May 13-15, 1984. SPE/DOE/GRI paper 12868.

2. Lorenz, J. C., P. Branagan, N. R. Warpinski, and A. R. Sattler. Fracture Characteristics and Reservoir Behavior of Stress-Sensitive Fracture Systems in Flat-Lying Lenticular Formations. Pres. at the SPE Urconventional Gas Tech. Symp., Louisville, KY. May 18-21, 1986. SPE paper 15244.

3. Lorenz, J. C. and S. J. Finley. Differences in Fracture Characteristics and Related Production of Natural Gas in Different Zones of the Mesaverde Formation, Northwestern Colorado. Pres. at the SPE 62nd Annual Tech. Conf. and Exhib. of the SPE, Dallas, TX, Sept. 27-30, 1987. SPE paper 16809 .

4. Branagan, P. T., C. L. Cipolla, S. J. Lee, and R. H. Wilmer. Comprehensive Well Testing and Modeling Pre- and Post-Fracture Well Performance of the MWX Lenticular Tight Gas Sands. Pres. at the SPE/DOE 1985 Low Permeability Gas Reservoirs Symp., Denver, CO, May 19-22. SPE/DOE paper 13867.

5. Warpinski, N. R., P. Branagan, A. R. Sattler, J. C. Lorenz, and D. A. Northrup, R. L. Mann, and K. H. Frohne. Fracturing and Testing Case Study of Paludal, Tight, Lenticular Gas Sands. SPE Formation Ekvaluation, Dec. 1987 pp. 535-545.

6. Branagan, P., C. L. Cipolla, S. J. Lee, and L. Yan. Case History of Hydraulic Fracture Performance in the Naturally Fractured Paludal Zone: The Transitory Effects of Damage. Pres. at the SPE/DOE Low Permeability Reservoir Symp., Denver, CO, May 18-19, 1987. SPE/DOE paper 16397.

7. Sattler, A. R. The Multiwell Experiment Core Program II. Pres. at the 1984 SPE/DOE/GRI Unconventional Gas Recovery Symp., Pittsburgh, PA, May 13-15, 1984. SPE paper 12854.

8. Randolph, P. L. Porosity and Permeability of Mesaverde Sandstone Core From the U.S. DOE Multiwell Experiment, Garfield County, Colorado. Pres. at the SPE/DOE Low Permeability Gas Reservoir Symp., Denver, CO, March 4-6, 1983. SPE/DOE paper 11765.

9. Soeder, D. J. and P. L. Randoiph. Porosity, Permeability and Pore Structure of the Tight Mesaverde Sandstone, Piceance Basin, Colorado. SPE Formation Evaluation, v. 2, No. 2, June, 1987, pp. 129-136.

10. Sattler, A. R., C. J. Raible, and B. L. Gall. Integration of Laboratory and Field Data for Insight on the Multiwell Experiment. Pres. at the SPE/DOE LOW Permeablitity Gas Reservoirs Symp., Denver, CO., May 19-22, 1986. SPE/DOE paper 13891. 
11. Gall B. L., and C. J. Raible. Molecular Size Studies of Degraded Fracturing Fluid Polymers. Pres. at the SPE International Symposium on Oilfield and Geothermal Chemistry, Phoenix, AZ, April 9-11, 1985. SPE paper 13566.

12. Sattler, A. R., P. J. Hudson, C. J. Raible, B. L. Gall, and D. R. Maloney. Laboratory Studies for the Design and Analys is of Hydraulic Fractured Stimulations in Lenticular. Tight Gas Reservoirs. Pres. at the SPE Unconventional Technology Symp. Louisville, KY, May 18-21, 1986. SPE paper 15245.

13. Volk, L. J., B. L. Gall, C. J. Raible, and H. B. Carroll, Jr. A Method for Evaluation of Formation Damage Due to Fracturing Fluids. Pres. at SPE/DOE Symp. on Low Permeability Reservoirs, Denver, CO, Mar. 14-16, 1983. SPE/DOE paper 11638.

14. Raible, C. J. and B. L. Gall. Hydraulic Fracturing Investigations for Low Permeability Sandstones. Proc., Western Gas Sands Subprogram Review, Morgantown Energy Technology Center, Oct. 18-19, 1983. Dept. of Energy Report No. DOE/METC/84-3.

15. Raible, C. J. and B. L. Gall. Laboratory Formation Damage Studies of Western Tight Sands. Pres. at SPE/DOE Joint Symp. On LOW Permeability Reservoirs, Denver, CO, May 19-22, 1985. SPE/DOE paper 13903.

16. Holditch, Stephen A. Factors Affecting Water Blocking and Gas Flow From Hydraulically Fractured Gas Wells. J. Pet. Tech., Dec. 1979, pp. 15151524.

17. Barkman, J. H., and D. H. Davidson. Measuring Water Quality and Predicting Well Impairment. J. Pet. Tech., July 1972, pp. 865-873.

18. Walsh, J. B. Effect of Pore Pressure and Confining Stress on Fracture Permeability. Int. J. Rock Mech. Min. Sci. and Geomech. Abstr. v. 18, 1981, pp. 429-435.

19. Jones, F. O. A Laboratory Study of the Effects of Confining Pressure on Fracture Flow and Storage Capacity in Carbonate Rocks. J. Pet. Tech., Jan. 1976, pp. 21-27.

20. Kranz, R. L., S. D. Frankel, T. Engelder, and C. H. Scholz. The Permeability of Whole and Jointed Barre Granite. Int. J. Rock Mech. Min. Sci. and Geomech. Abstra. v. 16, pp. 225-234, 1979.

21. Maloney, D. R., B. L. Gall, and C. J. Raible. Non-Darcy Flow Through Propped Fractures: Effects of Partial Saturation, Gel Damage, and Stress. Pres. at the SPE 62nd Ann. Tech. Conf. and Exhibit., Dallas, TX, Sept. 27-30, 1987. SPE paper 16899.

22. Jones, S. C. Using the Inertial Coefficient, $B$, To Characterize Heterogeneity in Reservoir Rock. Pres. at the SPE 62 nd Ann. Tech. Conf. and Exhibit., Dallas, TX, Sept. 27-30, 1987. SPE paper 16949. 
23. Noman, R. and J. S. Archer. The Effect of Pore Structure on NonDarcy Gas Flow in Some Low-Permeability Reservoir Rocks. Pres. at SPE/DOE LOW Permeability Reservoirs Symp., Denver, CO, May 18-19, 1987. SPE/DOE paper 16400.

24. Sattler, A. R., C. J. Raible, B. L. Gall and P. J. Gill. Frac Fluid Systems for Naturally Fractured Tight Gas Sandstones; A General Case Study from Multiwell Experiment Stimulations. To be presented at the 1988 SPE Gas Tech. Symp., Dallas. June 8-11. SPE paper 17717. 


\begin{tabular}{|llc|}
\hline \multicolumn{3}{|c|}{ Table 1. - Experimental conditions } \\
\hline Test & Parameter & Range \\
\hline Gas permeability & Mean gas pressure, MPa & $1.5-5.1$ \\
& Confining stress, MPa & $8.1-20.8$ \\
& Temperature, $K$ & $343-363$ \\
\hline Non-Darcy flow & Mean gas pressure, MPa & $0.1-0.5$ \\
& Confining stress, MPa & 6.99 \\
& Temperature, $K$ & $343-363$ \\
\hline Fluid-loss & Liquid pressure, MPa & 6.8 \\
& Conf ining stress, MPa & 20.4 \\
& Temperature, $K$ & 343 \\
& Time, hours & $1.5-2$ \\
\hline
\end{tabular}

\begin{tabular}{|c|c|c|c|c|c|c|c|}
\hline & & Table 2. - 6 & $\begin{array}{l}\text { led } \\
\text { ts of }\end{array}$ & $\begin{array}{l}\text { quids u } \\
\text { racked }\end{array}$ & $\begin{array}{l}\text { In format } \\
x \text { cores. }\end{array}$ & damage & \\
\hline \multirow[t]{2}{*}{ Gel No. } & \multirow[t]{2}{*}{ Polymer } & \multirow{2}{*}{$\begin{array}{l}\text { Conc. } \\
\mathrm{lb} / 1,000^{\mathrm{gal}}\end{array}$} & \multicolumn{5}{|c|}{ Additive } \\
\hline & & & $\mathrm{KCT}$ & Buffer & Surfactant & Breaker & 100 mesh sand \\
\hline 1 & HPG & 40 & $x$ & $x$ & & & \\
\hline $2 a$ & $\begin{array}{l}\text { Xanthan } \\
\text { gum }\end{array}$ & 20 & $x$ & & & & \\
\hline $\begin{array}{l}2 b \\
2 c \\
2 d \\
2 e \\
2 f\end{array}$ & & $\begin{array}{l}20 \\
20 \\
20 \\
20 \\
10\end{array}$ & $\begin{array}{l}x \\
x \\
x \\
x \\
x\end{array}$ & & $\begin{array}{l}x \\
x \\
x\end{array}$ & $\begin{array}{l}x \\
x \\
x \\
x\end{array}$ & $\begin{array}{l}x \\
x\end{array}$ \\
\hline 3 & $\begin{array}{l}\text { HEC in low } \\
\text { pH methano? }\end{array}$ & 20 & & & $x$ & & \\
\hline 4 & $\begin{array}{l}\text { HEC in } \\
\text { water }\end{array}$ & 40 & $\mathbf{x}$ & $x$ & & $\mathbf{x}$ & \\
\hline 5 & $\begin{array}{l}\text { poly- } \\
\text { acrylamide }\end{array}$ & 40 & & & & & \\
\hline
\end{tabular}

\begin{tabular}{|c|c|c|}
\hline $\begin{array}{r}\text { TABLE 3. - Gas permeabllity damag } \\
\text { fracturing fluid surfac }\end{array}$ & $\begin{array}{l}\text { cked cores resu } \\
\text { d breaker solut }\end{array}$ & from \\
\hline Core Solution additive & $\begin{array}{l}\text { Exposure time, } \\
\text { hr }\end{array}$ & $\mathrm{kg}_{\mathrm{m}}$ \\
\hline $\begin{array}{ll}\text { MWX-2 } 5837.0 & 2 X \mathrm{KCl} \\
& 2 X \mathrm{KCl}+\text { surfactants }\end{array}$ & $\begin{array}{l}18 \\
18\end{array}$ & $\begin{array}{l}0.117 \\
0.086\end{array}$ \\
\hline $\begin{array}{ll}\text { MWX-2 5836.8B } & 2 \% \mathrm{KCI} \\
& 2 \% \mathrm{KCI}+\text { surfactants + } \\
& \text { breaker }\end{array}$ & $\begin{array}{r}3 \\
18\end{array}$ & $\begin{array}{l}0.110 \\
0.060\end{array}$ \\
\hline $\begin{array}{ll}\text { MWX-2 } 5836.8 \mathrm{C} & 2 \% \mathrm{KCl} \\
& 2 \% \mathrm{KCl}+\text { surfactants + } \\
& \text { breaker } \\
\end{array}$ & $\begin{array}{l}18 \\
18\end{array}$ & $\begin{array}{l}0.140 \\
0.070\end{array}$ \\
\hline
\end{tabular}




\begin{tabular}{|c|c|c|c|c|}
\hline \multicolumn{5}{|c|}{$\begin{array}{l}\text { TABLE 4. - Permeabllity to gas of cracked inX } \\
\text { cores before and af ter gel damage }\end{array}$} \\
\hline $\begin{array}{l}\text { Core } \\
\text { Identification }\end{array}$ & Gel type* & $k_{g}$ before gel, & $\mathbf{k}_{\mathrm{g}}$ after gel, & $\frac{x^{R e d u c t i o n}}{x}$ \\
\hline \multicolumn{5}{|c|}{ "High" permeability cracked core } \\
\hline MWX-1 5842.0 & $\dddot{H P G}_{1}^{H P G}$ & 0.68 & 0.38 & 45 \\
\hline $\begin{array}{ll}\text { MWX-1 } & 5548.7 \\
\text { MWX-2 } & 5794.3\end{array}$ & $\begin{array}{l}\text { Xanthan gum } \\
2 \mathrm{a} \\
2 \mathrm{a}\end{array}$ & $50^{4.52}$ & $33^{0.37}$ & $\begin{array}{l}92 \\
34\end{array}$ \\
\hline \multicolumn{5}{|c|}{ "Low" permeability cracked core } \\
\hline MWX-1 $5842.0 C^{\circ}$ & $\stackrel{H P G}{1}^{H P}$ & 0.042 & 0.022 & 48 \\
\hline $\begin{array}{ll}\text { MWX-3 } & 5727.1 A \\
\text { MWX-1 } & 5842.0 A \\
\text { MWX-3 } & 5727.1 B-1 \\
\text { MWX-3 } & 5727.1 B-2 \\
\text { MWX-1 } & 5548.7 B \\
\text { MWX-1 } & 5548.7 C-2 \\
\text { MWX-1 } & 5548.7 C-3 \\
\text { MWX-2 } & 5736.1 B \\
\text { MWX-2 } & 5736.1 A \\
\text { MWX-1 } & 5727.4 B\end{array}$ & $\begin{array}{l}\text { Xanthan gum } \\
2 \mathrm{a} \\
2 \mathrm{~b} \\
2 \mathrm{c} \\
2 \mathrm{c} \\
2 \mathrm{c} \\
2 \mathrm{c} \\
2 \mathrm{c} \\
2 \mathrm{~d} \\
2 \mathrm{e} \\
2 \mathrm{f}\end{array}$ & $\begin{array}{l}0.190 \\
0.045 \\
0.052 \\
0.107 \\
0.136 \\
0.239 \\
0.372 \\
0.072 \\
0.076 \\
0.041\end{array}$ & $\begin{array}{l}0.020 \\
0.019 \\
0.024 \\
0.023 \\
0.017 \\
0.024 \\
0.020 \\
0.024 \\
0.030 \\
0.013\end{array}$ & $\begin{array}{l}90 \\
58 \\
54 \\
79 \\
88 \\
90 \\
94 \\
66 \\
61 \\
68\end{array}$ \\
\hline MWX-1 5841.9 & $\begin{array}{l}\text { HEC/methanol } \\
3\end{array}$ & 0.047 & 0.020 & 57 \\
\hline $\begin{array}{ll}\operatorname{mWX}-2 & 5736.1 \\
M W X-1 & 5836.8 B \\
M W X-1 & 5836.8 A\end{array}$ & $\begin{array}{l}\text { HEC/water } \\
4 \text { (3-day test) } \\
4 \text { (8-day test) }\end{array}$ & $\begin{array}{l}0.073 \\
0.153 \\
0.063\end{array}$ & $\begin{array}{l}0.034 \\
0.030 \\
0.013\end{array}$ & $\begin{array}{l}53 \\
80 \\
78\end{array}$ \\
\hline $\begin{array}{ll}\text { MWX-1 } & 5629.1 A \\
\text { MWX-1 } & 5629.18 \\
\text { MWX-1 } & 5727.4 C\end{array}$ & $\begin{array}{l}\text { polyacrylamide } \\
5 a \\
5 a \\
5 b\end{array}$ & $\begin{array}{l}0.135 \\
0.100 \\
0.039\end{array}$ & $\begin{array}{l}0.129 \\
0.095 \\
0.045\end{array}$ & $\begin{array}{l}4 \\
5 \\
0\end{array}$ \\
\hline
\end{tabular}




\begin{tabular}{|llllll|}
\hline \multicolumn{7}{c|}{ TABLE 5. - Polymer and core ident if ication for fluid-loss } \\
tests in flgure 1.
\end{tabular}

*As described in Table 2 .

\begin{tabular}{|c|c|c|c|c|c|c|}
\hline \multicolumn{7}{|c|}{$\begin{array}{c}\text { TABLE 6. - Non-Darcy flow parameters for cracks of several } \\
\text { estimated average crack widths }\end{array}$} \\
\hline $\begin{array}{l}\text { Core } \\
\text { Identification }\end{array}$ & Treatment & $\begin{array}{l}\text { Width, } \\
\text { um }\end{array}$ & $\begin{array}{l}k \\
\text { darcy }\end{array}$ & atm & atm- $\sec ^{2}$ & $r^{2}$ \\
\hline$M W X-1 \quad 6521.7$ & $d r y$ & 60 & 130 & 0 & $4.38 \times 10^{-5}$ & 0.972 \\
\hline$M W X-1 \quad 5478.9$ & biogel & $\begin{array}{l}30 \\
15\end{array}$ & $\begin{array}{l}0.075 \\
0.150\end{array}$ & $\begin{array}{l}0.2 \\
0.2\end{array}$ & $\begin{array}{l}9.12 \times 10^{-1} \\
2.28 \times 10^{-1}\end{array}$ & $\begin{array}{l}0.997 \\
0.997\end{array}$ \\
\hline MWX-1 5727.4A & biogel & $\begin{array}{l}30 \\
15\end{array}$ & $\begin{array}{l}0.039 \\
0.078\end{array}$ & $\begin{array}{l}0.4 \\
0.4\end{array}$ & $\begin{array}{l}6.83 \times 10^{-1} \\
1.60 \times 10^{-1}\end{array}$ & $\begin{array}{l}0.985 \\
0.985\end{array}$ \\
\hline$M W X-15727.4 C$ & brine & $\begin{array}{l}30 \\
15\end{array}$ & $\begin{array}{l}0.196 \\
0.392\end{array}$ & $\begin{array}{l}0.1 \\
0.1\end{array}$ & $\begin{array}{l}1.30 \times 10^{-1} \\
3.25 \times 10^{-1}\end{array}$ & $\begin{array}{l}0.941 \\
0.941\end{array}$ \\
\hline
\end{tabular}

\begin{tabular}{|c|c|c|}
\hline MWX-1 test interval & $\begin{array}{c}\text { Sustained gas production, Mo } \\
\text { Stimulation treatment (test time }\end{array}$ & \\
\hline $\begin{array}{l}\text { Paludal Zone } \\
\text { Sandstones } 3 \text { and } 4 \\
\text { perforation depth } \\
7076-7100 \mathrm{ft} \\
7120-7144 \mathrm{ft} \\
\end{array}$ & $\begin{array}{ccc}\text { Pre-fracture } & \text { Unpropped HPG Gel } & \text { Propped HPG gel } \\
\text { (2 weeks) } & (3-4 \text { weeks) } & \text { (1 week) } \\
250 & 200 & 150\end{array}$ & $\begin{array}{l}\text { Reentry after } 18 \text { months } \\
\text { ( } 3 \text { months) } \\
325\end{array}$ \\
\hline $\begin{array}{l}\text { Coastal Zone } \\
\text { rellow sandstone } \\
\text { perforat ion depth } \\
6428-6460 \mathrm{ft}\end{array}$ & $\begin{array}{ccc}\text { Pre-fracture } & \begin{array}{c}\text { Unpropped } \\
\text { nitrogen gas }\end{array} & \text { Propped nitrogen foam } \\
65 & 110 & 90\end{array}$ & \\
\hline $\begin{array}{l}\text { Fluvial Zone } \\
\text { 'B' sandstone } \\
\text { perforat ion depth } \\
5528-5845 \mathrm{ft}\end{array}$ & 18 & \\
\hline $\begin{array}{l}\text { Fluvial Zone } \\
\text { 'E' sandstone } \\
\text { perforat ion depth } \\
5535-5565 \mathrm{ft}\end{array}$ & 220 & \\
\hline
\end{tabular}




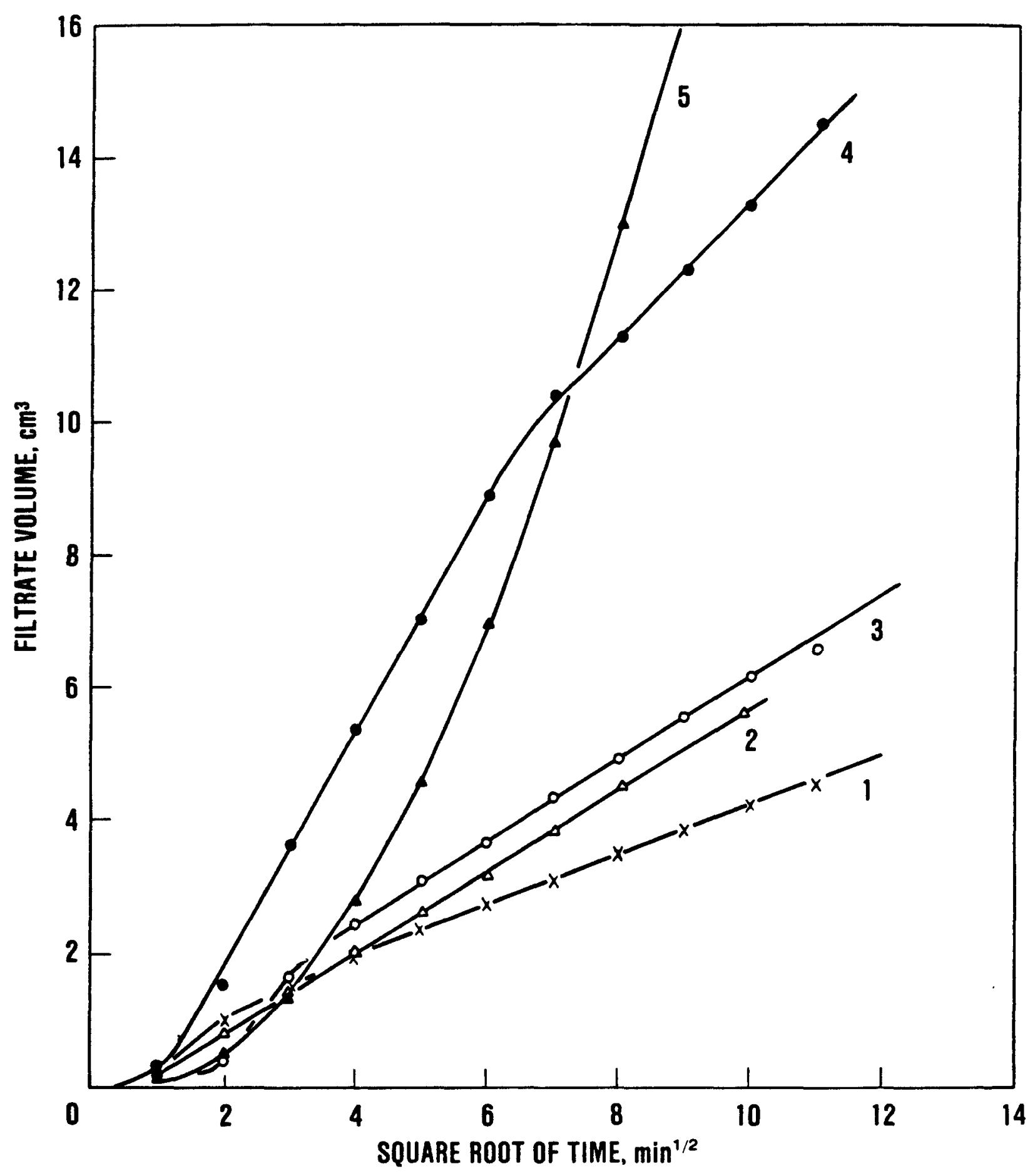

FIGURE 1. - Fluid leakoff as a function of the square root of time. Tests were conducted using cracked MWX cores and various gelled solutions as described in the text. 


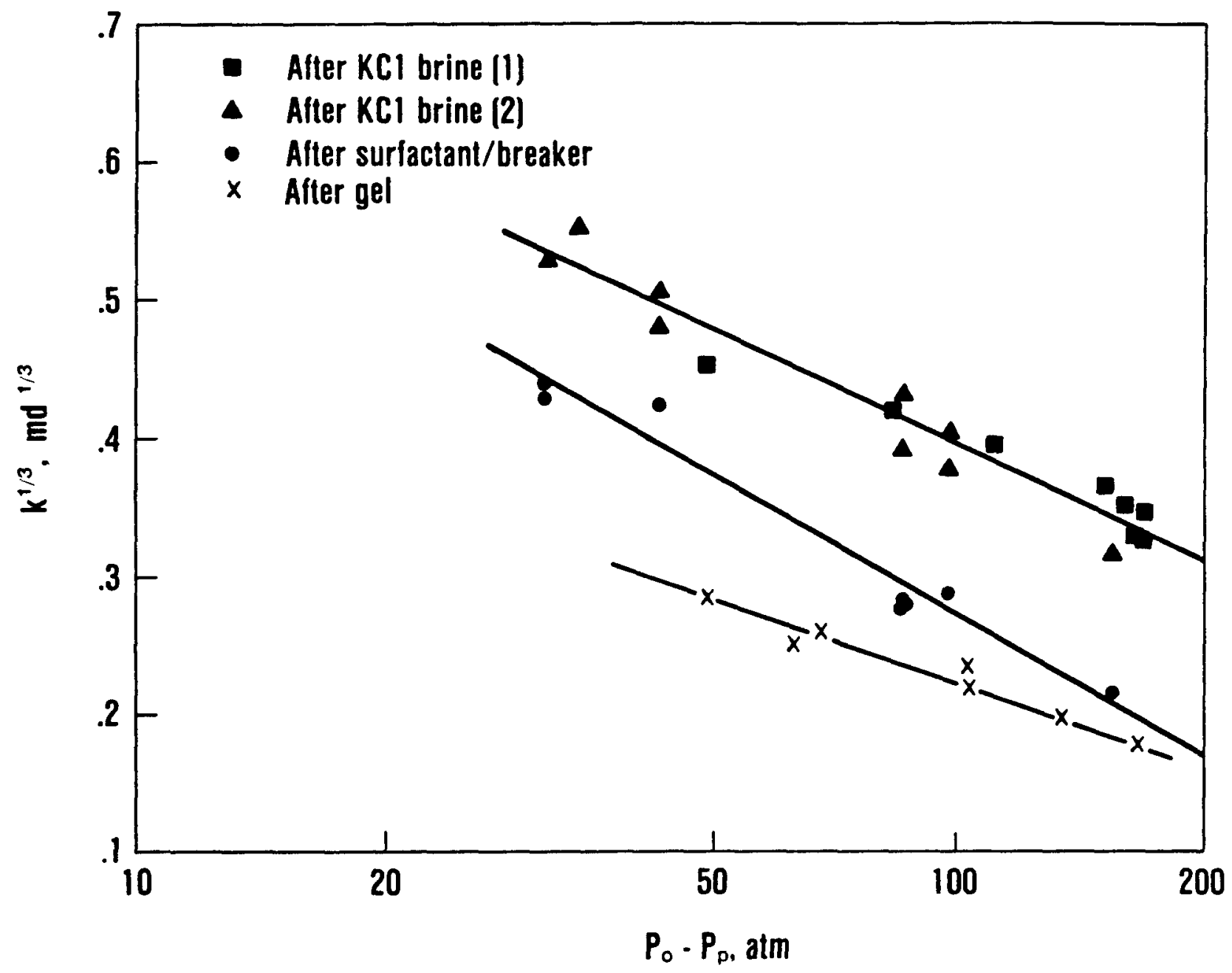

FIGURE 2. - Effect of net stress on effective permeability of cracked MWX core. 


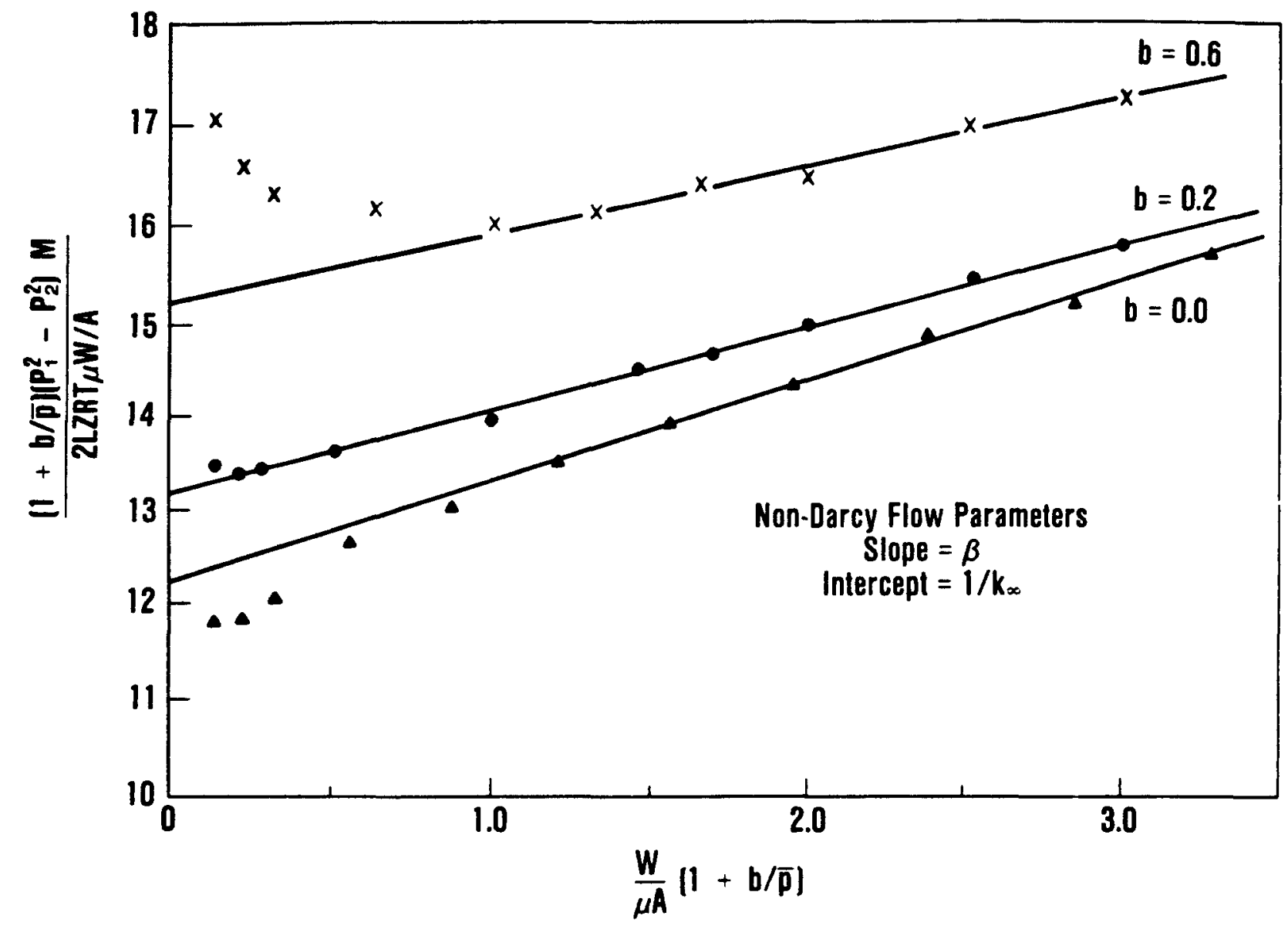

FIGURE 3. - Calculation of non-darcy flow parameters using Eq. 2. for several values of the gas slippage parameter, $b$. 


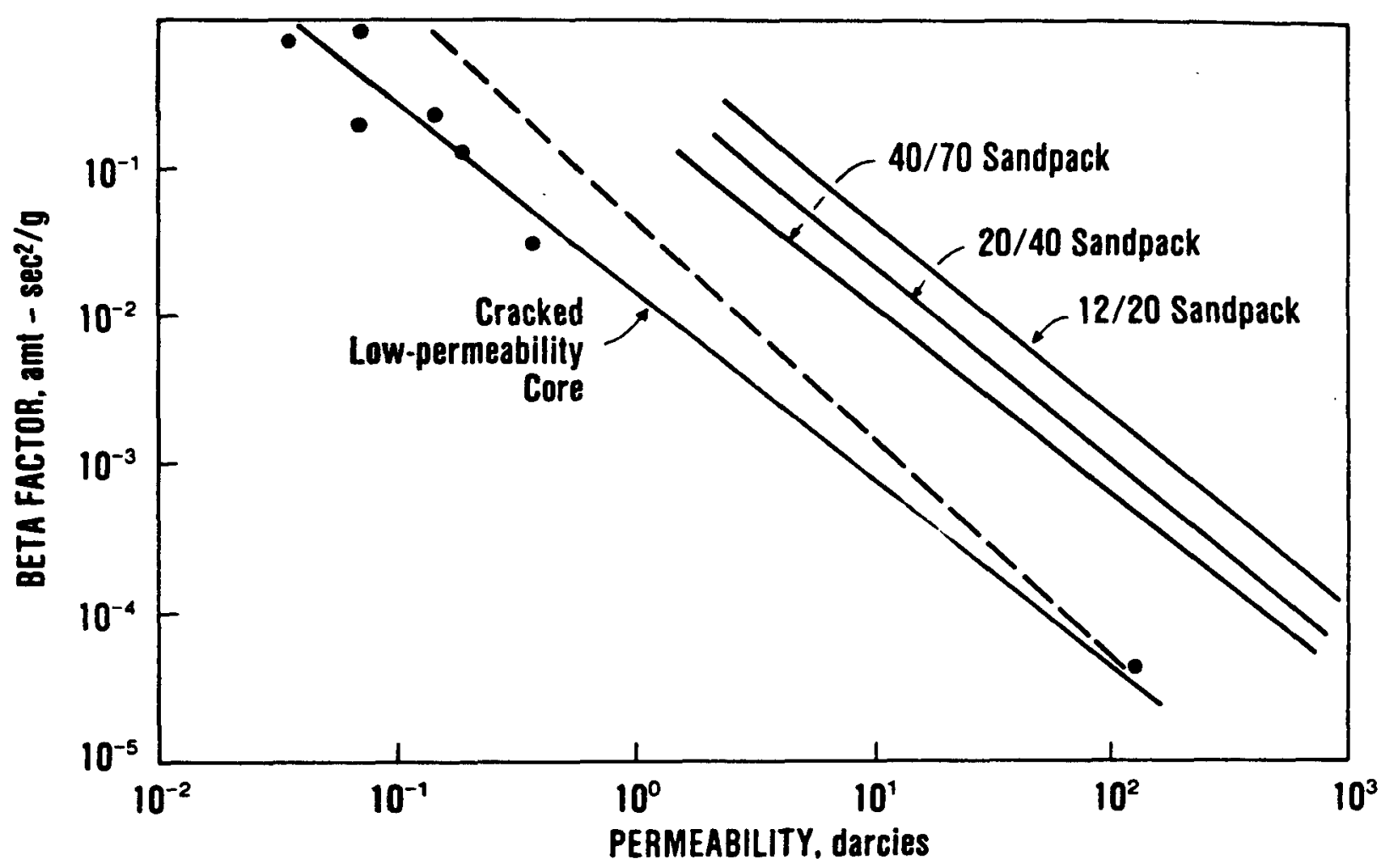

FIGURE 4. - Correlation of non-darcy flow parameters, $\beta$ and $k$, for several types of porous media. The dashed line represents a correlation of $B$ versus $k$ data for consolidated cores reported by S. C. Jones. 